\title{
PENERAPAN KOOPERATIF TEAMS GAMES TOURNAMENT MENINGKATKAN HASIL BELAJAR TAKTIK DAN STRATEGI PERLOMBAAN ATLETIK LEMPAR LEMBING
}

\author{
I Kadek Untung Sudiatmaja ${ }^{1, *}$ \\ ${ }^{1}$ Universitas Pendidikan Ganesha
}

\begin{abstract}
Abstrak
Penelitian ini bertujuan meningkatkan hasil belajar taktik dan strategi perlombaan atletik lempar lembing melalui penerapan model pembelajaran kooperatif tipe TGT pada peserta didik kelas XII MIPA 1 SMA Negeri 1 Singaraja tahun pelajaran $2017 / 2018$. Penelitian ini adalah penelitian tindakan kelas yang dilaksanakan dalam dua siklus, yang terdiri dari rencana tindakan, pelaksanaan tindakan, observasi atau evaluasi dan refleksi. Subjek penelitian peserta didik kelas XII MIPA 1 SMA Negeri 1 Singaraja, berjumlah 30 orang dengan rincian 20 orang putra dan 10 orang putri. Data dianalisis menggunakan statistik deskriptif.

Hasil analisis data rata-rata nilai hasil belajar taktik dan strategi perlombaan atletik lempar lembing siklus I yaitu pada kompetensi sikap sebesar 87, pengetahuan 85 dan kompetensi keterampilan sebesar 86 dan rata-rata nilai hasil belajar pada siklus II yaitu pada kompetensi sikap sebesar 89, pengetahuan 94 dan kompetensi keterampilan sebesar 89. Dari data hasil belajar tersebut dapat dikatakan bahwa hasil belajar taktik dan strategi perlombaan atletik lempar lembing pada siklus I ke siklus II mengalami peningkatan. Berdasarkan hasil analisis data dan pembahasan dapat disimpulkan bahwa hasil belajar taktik dan strategi perlombaan atletik lempar lembing meningkat melalui penerapan model pembelajaran kooperatif tipe TGT pada peserta didik kelas XII MIPA 1 SMA Negeri 1 Singaraja tahun pelajaran 2017/2018. Disarankan kepada guru penjasorkes untuk menerapkan model pembelajaran kooperatif tipe TGT karena dapat meningkatkan hasil belajar taktik dan strategi perlombaan atletik lempar lembing.
\end{abstract}

Kata-kata kunci:

kooperatif tipe TGT, hasil belajar, lempar lembing

\section{PENDAHULUAN}

Selama pendidikan masih ada, maka selama itu pula masalah-masalah tentang pendidikan akan selalu muncul dan orang pun tak akan henti-hentinya untuk terus membicarakan dan memperdebatkan tentang keberadaannya, mulai dari hal-hal yang bersifat fundamental-filsafiah sampai dengan hal-hal yang sifatnya teknis operasional. Sebagian besar pembicaraan tentang pedidikan terutama tertuju pada bagaimana upaya untuk menemukan cara terbaik guna mencapai pendidikan yang bermutu dalam rangka menciptakan sumber daya manusia yang handal, baik dalam bidang akademis, sosio-personal, maupun vokasional. Dengan hal tersebut pula proses pembelajaran pendidikan jasmani olahraga dan kesehatan (PJOK) harus mengikuti pola perkembangan untuk mencapai proses pembelajaran yang lebih baik.

Berdasarkan observasi awal yang telah peneliti lakukan di SMA Negeri 1 Singaraja pada hari/tanggal rabu, 13 September 2017 yang bertempat di Lapangan Mayor Metra Singaraja pada pukul 05.30 - 07.45 wita, dikelas XII MIPA 1 yang berjumlah 30 peserta didik yaitu 20 orang putra dan 10 orang putri, ditemukan hasil belajar taktik dan strategi perlombaan atletik lempar lembing peserta didik yang belum tuntas dan perlu ditingkatkan.

Adapun data hasil belajar yang diperoleh dengan mengamati aktivitas dan hasil belajar siswa, masih terdapatnya siswa yang belum tuntas dapat terlihat dari kompetensi sikap, kompetensi pengetahuan dan kompetensi keterampilan. 


\begin{tabular}{|c|c|c|c|c|c|c|}
\hline KKM & Nilai & $\begin{array}{c}\text { Jumlah } \\
\text { Peserta Didik }\end{array}$ & Kriteria & Predikat & $\begin{array}{c}\text { Presentase } \\
(\%)\end{array}$ & Keterangan \\
\hline \multirow{7}{*}{82} & $91-100$ & 4 & Sangat Baik & A & $13,33 \%$ & 30 orang \\
\hline & & 23 & & & $76,67 \%$ & $(90,00 \%)$ \\
\hline & $80-90$ & & Baik & B & & \\
\hline & $70-79$ & 3 & Cukup & $\mathrm{C}$ & $10 \%$ & 3 orang \\
\hline & & 0 & & & $0 \%$ & $(10,00 \%)$ \\
\hline & $<60$ & & Kurang & D & & \\
\hline & Jumlah & 30 & & & $100 \%$ & belum tuntas \\
\hline
\end{tabular}

Ketidak tuntasan ini terlihat dari a) masih ada peserta didik yang belum tampil bersih dan rapi dalam belajar, b) mengganggu temannya belajar, c) datang terlambat, d) kurangnya kerjasama tim dalam belajar.

Tabel 2 Kompetensi Pengetahuan

\begin{tabular}{|c|c|c|c|c|c|c|}
\hline KKM & Nilai & $\begin{array}{c}\text { Jumlah } \\
\text { Peserta Didik }\end{array}$ & Kriteria & Predikat & $\begin{array}{c}\text { Presentase } \\
(\%)\end{array}$ & Keterangan \\
\hline \multirow{7}{*}{82} & $91-100$ & 0 & Sangat Baik & A & $0 \%$ & 17 orang \\
\hline & & 17 & & & $56,67 \%$ & $(56,67 \%)$ \\
\hline & $80-90$ & & Baik & B & & \\
\hline & $70-79$ & 13 & Cukup & $\mathrm{C}$ & $43,33 \% "$ & 13 orang \\
\hline & & 0 & & & $0 \%$ & $(43,33 \%)$ \\
\hline & $<60$ & & Kurang & D & & \\
\hline & Jumlah & 30 & & & $100 \%$ & belum tuntas \\
\hline
\end{tabular}

Ketidak tuntas itu terlihat dari kemampuan peserta didik dalam menganalisa taktik dan strategi perlombaan lempar lembing.

Tabel 3 Kompetensi Keterampilan

\begin{tabular}{|c|c|c|c|c|c|c|}
\hline KKM & Nilai & $\begin{array}{c}\text { Jumlah } \\
\text { Peserta Didik } \\
\end{array}$ & Kriteria & Predikat & $\begin{array}{c}\begin{array}{c}\text { Presentase } \\
(\%)\end{array} \\
\end{array}$ & Keterangan \\
\hline \multirow{6}{*}{82} & $91-100$ & 2 & Sangat Baik & A & $6,67 \%$ & 13 orang \\
\hline & & 11 & & & $36,67 \%$ & $(43,34 \%)$ \\
\hline & $80-90$ & & Baik & B & & \\
\hline & $70-79$ & $\begin{array}{c}17 \\
0\end{array}$ & Cukup & $\mathrm{C}$ & $\begin{array}{c}56,66 \% \\
0 \%\end{array}$ & $\begin{array}{c}17 \text { orang } \\
(56,66 \%)\end{array}$ \\
\hline & $<60$ & & Kurang & D & & belum tuntas \\
\hline & Jumlah & 30 & & & $100 \%$ & \\
\hline
\end{tabular}

Ketidak tuntasan itu dari pegangan lembing belum sempurna, masih binggung dalam melakukan gerakan langkah membawa lembing, dan jatuhnya lembing masih banyak pada badan dan ekor lembing yang mengenai tanah.

Hasil refleksi awal yang peneliti lakukan tersebut yaitu (1) dari siswa: guru belum menjelaskan materi dengan lengkap, guru mempratikkan gerakan terlalu cepat (2) dari penelti: guru hanya menyuruh siswa mempelajari buku siswa dan tidak menjelaskan secara lengkap dan guru hanya mendemonstrasikan gerakan sebagai contoh. Untuk mengatasi permasalahan yang ada, yang dilakukan peneliti yaitu 
menjelaskan materi secara jelas dan lengkap dengan menggunakan media gambar serta memberikan contoh dengan pelan agar setiap langkah keterampilan dapat dikuasai dengan baik

Sehubungan dengan hal tersebut peneliti tertarik untuk memecahkan masalah tersebut dengan melakukan penelitian mengkombinasikan pendekatan saintifik dengan model pembelajaran kooperatif. Kemdikbud (2013) memberikan konsepsi bahwa pendekatan ilmiah (scientific approach) dalam pembelajaran mencakup komponen: mengamati, menanya, mengumpulkan informasi, mengasosiasi, dan mengkomunikasikan.

Peneliti yakin bahwa pendekatan saintifik dan model pembelajaran kooperatif tipe TGT akan dapat membantu peserta didik dalam pembelajaran karena dengan peserta didik dapat menelaah mata pelajaran dan dapat mengaktualisasi diri serta kerjasama interaksi baik peserta didik dan guru akan membuat suasana pembelajaran tidak membosankan. Adanya tim, permainan dan turnamen dalam pembelajaran kooperatif tipe TGT dapat menimbulkan rasa senang dan tanggung jawab peserta didik untuk memberikan kontribusi yang positif pada kelompoknya dan meningkatkan motivasi peserta didik untuk mengikuti proses pembelajaran sehingga nantinya dapat berpengaruh terhadap peningkatan hasil belajar.

Adapaun beberapa penemuan dari penelitian terdahulu adalah; Ni Putu Ria Tejasari, (2010: 113) menemukan bahwa aktivitas dan hasil belajar teknik passing bola basket meningkat melalui implementasi model pembelajaran kooperatif tipe Teams Games Tournaments (TGT) pada siswa kelas X.1 SMA Negeri 1 Kerambitan Tahun pelajaran 2010/2011. Ni Putu Ayu Rikayanti, (2012: 115) menemukan bahwa motivasi dan hasil belajar meningkat melalui penerapan model pembelejaran kooperatif tipe Teams games tournaments (TGT) pada siswa kelas VIII C SMP Negeri 2 Penebel Tahun Pelajaran 2011/2013. Nurita Yulifatul Janah (2011) menemukan bahwa hasil belajar meningkatkan melalui penerapan pembelajaran kooperatif tipe TGT menggunakan media permainan ular tangga pada siswa kelas VIII SMP Negeri 2 Tumpang.

Berdasarkan permasalahan tersebut di atas, maka peneliti akan melakukan penelitian dengan judul "Penerapan Model Pembelajaran Kooperatif Tipe Teams Games Tournament (TGT) untuk Meningkatkan Hasil Belajar Taktik dan Strategi Perlombaan Atletik Lempar Lembing pada Peserta Didik Kelas XII MIPA 1 SMA Negeri 1 Singaraja Tahun Pelajaran 2017/2018”..

\section{METODE PENELITIAN}

Jenis penelitian adalah pengolonggan penelitian berdasarkan pedoman dari segi mana penggolongan itu di tinjau (Kanca I Nyoman, 2010: 5). Jenis penelitian yang digunakan dalam penelitian ini adalah penelitian tindakan kelas (PTK) yang pelaksanaanya berupa penyajian atau latihan di lapangan. PTK merupakan suatu bentuk penelitian yang bersifat reflektif dengan melakukan tindakantindakan tertentu agar dapat memperbaiki dan atau meningkatkan praktek-praktek pembelajaran di kelas secara lebih profesional (Kanca I Nyoman, 2010: 108).

Ojan SN dalam (Kanca I Nyoman, 2010: 115) menyebutkan terdapat empat bentuk PTK, yaitu: (a) guru sebagai peneliti, (b) peneliti tindakan kolaboratif, (c) simultan-terintegrasi, dan (d) administrasi sosial eksperimental.

Bentuk penelitian tindakan kelas yang memandang guru sebagai peneliti mempunyai ciri-ciri penting yaitu sangat berperannya guru itu sendiri dalam proses penelitian tindakan kelas (PTK). Dalam bentuk ini, tujuan utama penelitian tindakan kelas adalah untuk meningkatkan praktek-praktek pembelajaran di kelas, dimana guru terlibat secara penuh dalam proses perencanaan, aksi (tindakan) dan refleksi.

\section{HASIL DAN PEMBAHASAN}

Penelitian ini telah dilaksanakan pada hari Rabu, 27 September dan Rabu, 04 Oktober di Lapangan Mayor Metra Singaraja pada pukul 05.30-07.45 wita, pada kelas XII MIPA 1 SMA Negeri 1 Singaraja tahun ajaran 2017/2018 yang berjumlah 30 peserta didik yaitu yaitu 20 orang putra dan 10 orang putri. Penelitian ini dilaksanakan sebanyak dua siklus, dimana setiap siklusnya hanya 1 kali pertemuan. 
Tabel 4. Data Hasil Belajar Kompetensi Sikap Siklus I

\begin{tabular}{ccccccc} 
KKM & Nilai & $\begin{array}{c}\text { Jumlah } \\
\text { Peserta Didik }\end{array}$ & Kriteria & Predikat & $\begin{array}{c}\text { Presentase } \\
\text { (\%) }\end{array}$ & Keterangan \\
\hline \multirow{2}{*}{82} & $91-100$ & 9 & Sangat Baik & A & $30,00 \%$ & 30 orang \\
& $80-90$ & 21 & Baik & B & $70,00 \%$ & $(100 \%)$ tuntas \\
& $70-79$ & - & Cukup & C & - & - \\
& $<60$ & - & Kurang & D & - & $\mathbf{1 0 0 \%}$ \\
\hline
\end{tabular}

Penelitian hasil belajar siswa (katagori sikap) pada materi merancang taktik dan strategi perlombaan lempar lembing pada siklus I diperoleh data hasil belajar dimana siswa yang tuntas sebanyak 27 siswa dengan persentase 90,00\% dan yang tidak tuntas sebanyak 3 siswa dengan persentase $10,00 \%$ dengan rincian kategori hasil belajar sebagai berikut: siswa dengan kategori sangat baik sebanyak 4 orang dengan persentase 13,33\%, siswa dengan kategori baik sebanyak 23 orang dengan persentase 76,67\%, siswa dengan kategori cukup baik sebanyak 3 orang dengan persentase 10,00\%, siswa dengan kategori kurang baik sebanyak 0 orang dengan persentase $0 \%$.

Tabel 5 Data Hasil Belajar Kompetensi Pengetahuan Siklus I

\begin{tabular}{|c|c|c|c|c|c|c|}
\hline \multirow[t]{2}{*}{ KKM } & & Jumlah & \multicolumn{4}{|c|}{ Presentase } \\
\hline & Nilai & $\begin{array}{c}\text { Peserta } \\
\text { Didik }\end{array}$ & Kriteria & Predikat & $(\%)$ & Keterangan \\
\hline & $91-100$ & 9 & Sangat Baik & $\mathrm{A}$ & $30,00 \%$ & 26 orang \\
\hline & $80-90$ & 17 & Baik & B & $57,00 \%$ & $(87,00 \%)$ tuntas \\
\hline \multirow[t]{3}{*}{82} & $70-79$ & 4 & Cukup & $\mathrm{C}$ & $13,00 \%$ & 4 orang \\
\hline & $<60$ & - & Kurang & $\mathrm{D}$ & - & tuntas \\
\hline & Jumlah & 30 & & & $100 \%$ & \\
\hline
\end{tabular}

Penelitian hasil belajar siswa (katagori pengetahuan) pada materi merancang taktik dan strategi perlombaan lempar lembing pada siklus I diperoleh data hasil belajar dimana siswa yang tuntas sebanyak 26 siswa dengan persentase 87,00\% dan yang tidak tuntas sebanyak 4 siswa dengan persentase $13,00 \%$ dengan rincian kategori hasil belajar sebagai berikut: siswa dengan kategori sangat baik sebanyak 9 orang dengan persentase 30,00\%, siswa dengan kategori baik sebanyak 17 orang dengan persentase $57,00 \%$, siswa dengan kategori cukup baik sebanyak 4 orang dengan persentase $13,00 \%$, siswa dengan kategori kurang baik sebanyak 0 orang dengan persentase $0 \%$

Tabel 6. Data Hasil Belajar Kompetensi Keterampilan Siklus I

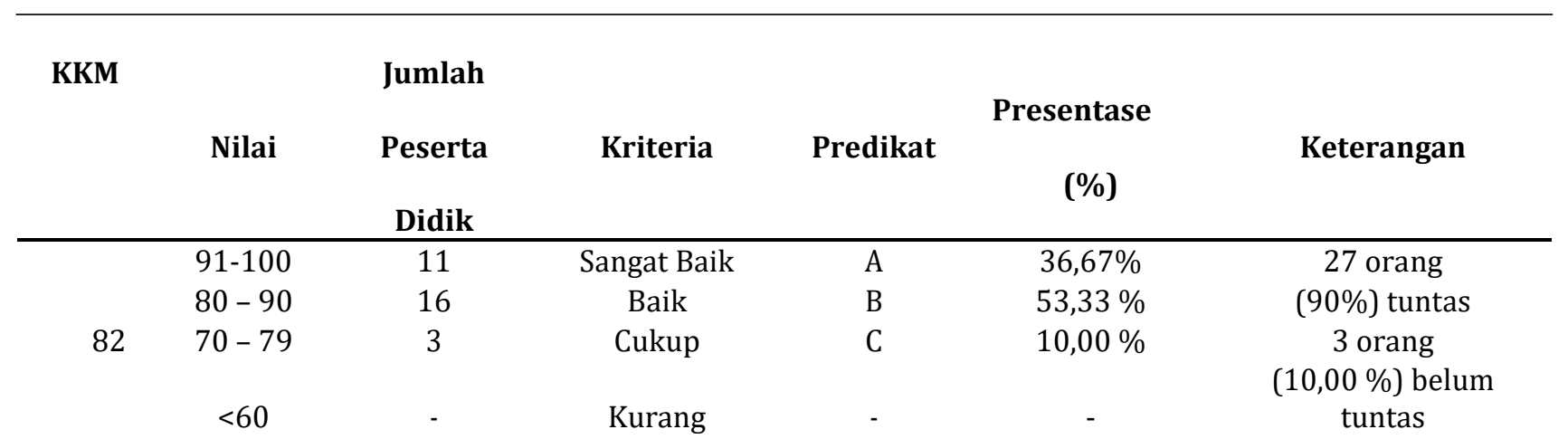


Penelitian hasil belajar siswa (katagori keterampilan) pada materi merancang taktik dan strategi perlombaan lempar lembing pada siklus I diperoleh data hasil belajar dimana siswa yang tuntas sebanyak 27 siswa dengan persentase 90,00\% dan yang tidak tuntas sebanyak 3 siswa dengan persentase 10,00\% dengan rincian kategori hasil belajar sebagai berikut: siswa dengan kategori sangat baik sebanyak 11 orang dengan persentase 36,67\%, siswa dengan kategori baik sebanyak 16 orang dengan persentase 53,33\%, siswa dengan kategori cukup baik sebanyak 3 orang dengan persentase $10,00 \%$, siswa dengan kategori kurang baik sebanyak 0 orang dengan persentase $0 \%$

Tabel 7. Data Hasil Belajar Kompetensi Sikap Siklus II

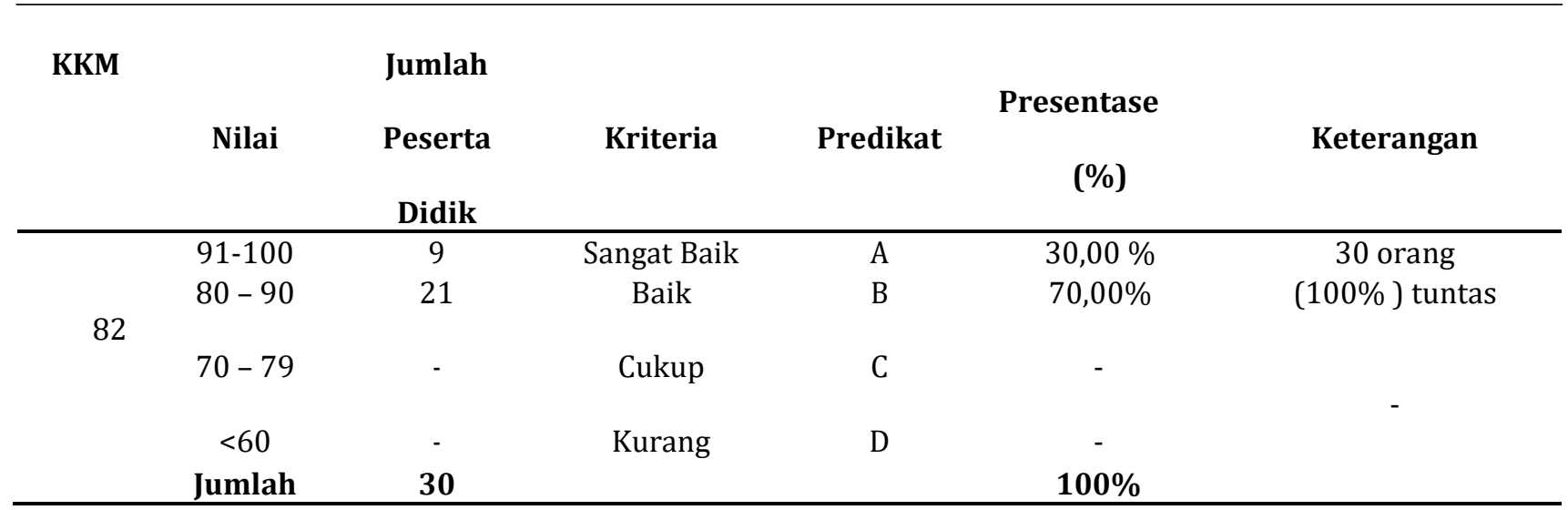

Penelitian hasil belajar siswa (katagori keterampilan) pada materi merancang taktik dan strategi perlombaan lempar lembing pada siklus I diperoleh data hasil belajar dimana siswa yang tuntas sebanyak 30 siswa dengan persentase 100,00\% dan yang tidak tuntas sebanyak 0 siswa dengan persentase $0 \%$.

Tabel 8. Data Hasil Belajar Kompetensi Pengetahuan Siklus II

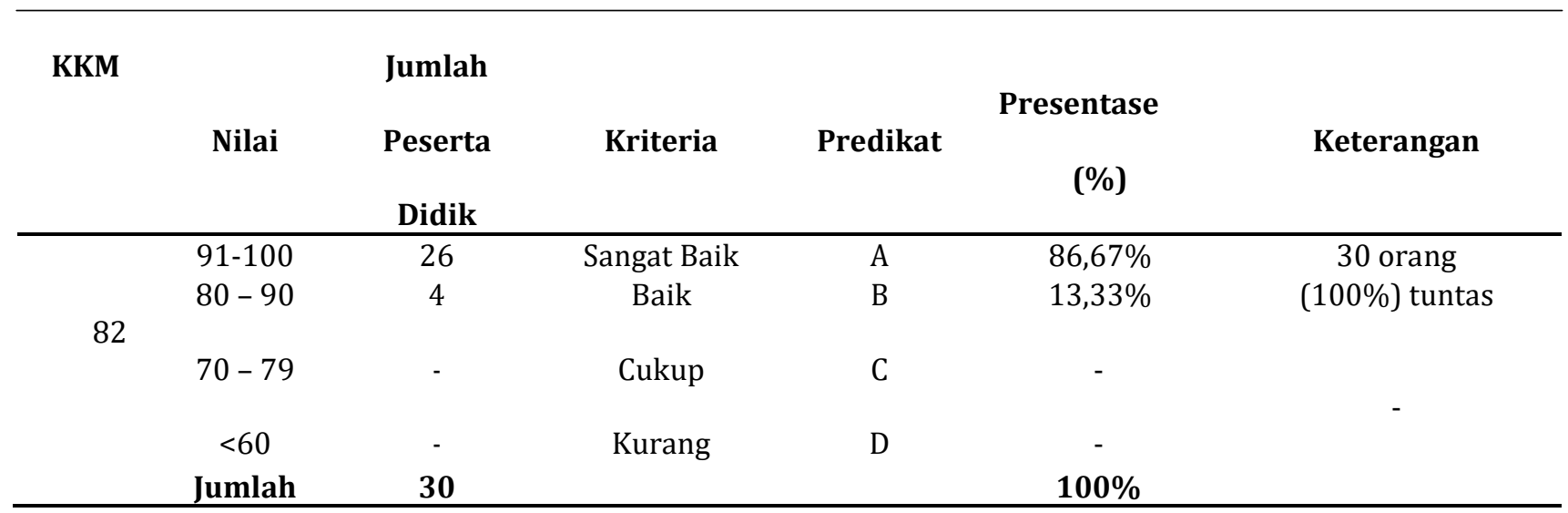

Penelitian hasil belajar siswa (katagori pengetahuan) pada materi merancang taktik dan strategi perlombaan lempar lembing pada siklus II diperoleh data hasil belajar dimana siswa yang tuntas sebanyak 30 siswa dengan persentase 100,00\% dan yang tidak tuntas sebanyak 0 siswa dengan persentase $0 \%$. 
Tabel 9. Data Hasil Belajar Kompetensi Keterampilan Siklus II

\begin{tabular}{ccccccc}
\hline KKM & & Jumlah & & & & \\
& Nilai & Peserta & Kriteria & Predikat & Presentase & Keterangan \\
& & Didik & & & (\%) & \\
\hline 82 & $91-100$ & 13 & Sangat Baik & A & $43,33 \%$ & 30 orang \\
& $80-90$ & 17 & Baik & B & $56,67 \%$ & $(100 \%)$ tuntas \\
& $70-79$ & - & Cukup & C & - & - \\
& $<60$ & - & Kurang & D & - & \\
\hline
\end{tabular}

Penelitian hasil belajar siswa (katagori pengetahuan) pada materi merancang taktik dan strategi perlombaan lempar lembing pada siklus II diperoleh data hasil belajar dimana siswa yang tuntas sebanyak 30 siswa dengan persentase 100,00\% dan yang tidak tuntas sebanyak 0 siswa dengan persentase $0 \%$.

Penelitian ini diawali dengan melakukan obeservasi awal yang dilakukan oleh peneliti pada siswa kelas XII MIPA 1 SMA Negeri 1 Singaraja, bersamaan saat melaksanakan pengajaran PJOK berkaitan dengan PPL-PPG di sekolah tersebut. Peserta didik kelas XII MIPA 1 SMA Negeri 1 Singaraja mengalami masalah dalam hasil belajar PJOK. Hal ini dapat dilihat dari nilai PJOK yang dicapai oleh peserta didik belum mencapai standar yang ditetapkan.

Merefleksi hasil belajar yang terjadi tersebut, terungkap beberapa permasalahan yang teridentifikasi sebagai penyebab belum optimalnya pencapaian hasil belajar PJOK. Pertama, peserta didik kurang siap dalam menerima proses pembelajaran. Hal ini disebabkan karena peserta didik belum berinisyatif mempelajari materi terlebih dahulu di rumah. Mereka lebih memilih untuk menunggu penjelasan dari guru. Hal ini bermuara pada kurangnya keaktifan peserta didik dalam pembelajaran di kelas. Kenyataan seperti ini tidak dapat menjawab tuntutan dari kurikulum 2013, kurikulum ini menuntut agar peserta didik mengkonstruksi pengetahuannya secara mandiri sesuai dengan pandangan konstruktivis. Perkembangan berpikir peserta didik juga sangat dipengaruhi oleh model belajar dan media pembelajaran yang tepat. Kedua, peserta didik kurang terlibat aktif dalam proses pembelajaran, karena guru jarang memberikan kesempatan kepada peserta didik untuk menampilkan hasil pekerjaannya di depan kelas apakah tugas yang dibuatnya sudah benar atau salah. Hal ini menyebabkan peserta didik kurang memahami apa yang sedang dipelajari dan peserta didik enggan untuk bertanya meskipun mereka belum paham tentang tugas yang diberikan. Selain itu, masih tampak kebiasaan peserta didik yang cendrung masih menunggu jawaban dan instruksi dari guru. Kondisi ini bermuara pada pasifnya peserta didik di dalam kelas dan pembelajaran menjadi tidak bermakna. Ketiga, sikap peserta didik untuk belajar PJOK masih rendah. Peserta didik kurang memperhatikan penjelasan guru selama pembelajaran berlangsung, hal ini menunjukkan bahwa peserta didik enggan untuk belajar. Peserta didik kurang berpartisipasi dalam penyelesaian masalah yang diberikan dan mereka akan mengerjakannya jika ditunjuk oleh guru. Selain itu, jarang ada peserta didik yang bertanya baik ketika pembelajaran berlangsung maupun setelah pembelajaran berakhir, padahal mereka belum benar-benar memahami materi yang telah disajikan. Hal ini menunjukkan rendahnya sikap peserta didik terhadap pembelajaran PJOK.

Dari hasil penelitian pada siklus I dengan materi taktik dan strategi perlombaan lempar lembing bahwa pada kompetensi sikap 30 orang sudah tuntas dengan rata-rata nilai secara klasikal 87, pengetahuan 26 orang sudah tuntas dengan rata-rata nilai secara klasikal 85 dan keterampilan 27 orang sudah tuntas dengan rata-rata nilai secara klasikal 85. Dapat disimpulkan, Penelitian pada siklus I belum berhasil karena dari ketiga kompetensi yang nilai yaitu kompetensi pengetahuan dan keterampilan masih ada yang belum memenuhi KKM yaitu 82 sesuai yang berlaku di SMA Negeri 1 Singaraja.

Selanjutnya dilakukan refleksi dengan memperhatikan data hasil belajar peserta didik

pada siklus I, permasalahan-permasalahan yang dihadapi adalah: (a) kompetensi pengetahuan, masih kurangnya pemahaman peserta didik mengenai materi taktik dan strategi perlombaan lempar lembing, hal ini terlihat dari rendahnya nilai yang diperoleh dari hasil tes tulis atau pelaporan, dan (b) kompetensi keterampilan, peserta didik masih mengalami kesalahan dalam merancang dan megevaluasi gerakan langkah membawa lembing, dan pegangan lembing masih lemah dan keseimbangan dalam melangkah dan 
melempar masih belum bagus. Berdasarkan permasalahan tersebut, maka tindakan perbaikan yang dilakukan adalah: (a) peneliti menjelaskan kembali dengan menekankan pada kesalahan yang terjadi dalam menganalisa vidio materi taktik dan strategi perlombaan lempar lembing secara bertahap, dan (b) memberikan bimbingan kepada peserta didik yang masih kesulitan dan salah dalam melakukan rancangan dan evaluasi gerakan taktik dan strategi perlombaan lempar lembing sehingga hasil yang diperoleh bisa lebih optimal.

Berdasarkan uraian diatas, maka penelitian ini dilanjutkan ke siklus II. Hasil dari refleksi siklus I ini digunakan sebagai referensi dalam melaksanakan penelitian pada siklus II dengan tujuan untuk dapat meningkatkan hasil belajar yang lebih baik.Selanjutnya dilakukan refleksi dengan memperhatikan data hasil belajar peserta didik pada siklus I, permasalahan-permasalahan yang dihadapi adalah: (a) kompetensi pengetahuan, masih kurangnya pemahaman peserta didik mengenai materi taktik dan strategi perlombaan lempar lembing, hal ini terlihat dari rendahnya nilai yang diperoleh dari hasil tes tulis atau pelaporan, dan (b) kompetensi keterampilan, peserta didik masih mengalami kesalahan dalam merancang dan megevaluasi gerakan langkah membawa lembing, dan pegangan lembing masih lemah dan keseimbangan dalam melangkah dan melempar masih belum bagus. Berdasarkan permasalahan tersebut, maka tindakan perbaikan yang dilakukan adalah: (a) peneliti menjelaskan kembali dengan menekankan pada kesalahan yang terjadi dalam menganalisa vidio materi taktik dan strategi perlombaan lempar lembing secara bertahap, dan (b) memberikan bimbingan kepada peserta didik yang masih kesulitan dan salah dalam melakukan rancangan dan evaluasi gerakan taktik dan strategi perlombaan lempar lembing sehingga hasil yang diperoleh bisa lebih optimal.

Berdasarkan uraian diatas, maka penelitian ini dilanjutkan ke siklus II. Hasil dari refleksi siklus I ini digunakan sebagai referensi dalam melaksanakan penelitian pada siklus II dengan tujuan untuk dapat meningkatkan hasil belajar yang lebih baik.

Dari hasil penelitian pada siklus II dengan materi taktik dan strategi perlombaan lempar lembing bahwa pada kompetensi sikap 30 orang sudah tuntas dengan rata-rata nilai secara klasikal 89, pengetahuan 30 orang sudah tuntas dengan rata-rata nilai secara klasikal 94 dan keterampilan 30 orang sudah tuntas dengan rata-rata nilai secara klasikal 89. Berdasarkan data hasil belajar tersebut dapat dinyatakan bahwa hasil belajar PJOK dari siklus I ke siklus II mengalami peningkatan.

Dapat disimpulkan, Penelitian pada siklus II sudah berhasil karena dari ketiga kompetensi yang nilai yaitu kompetensi sikap, pengetahuan dan keterampilan sudah memenuhi bahkan melewati standar KKM yaitu 82 sesuai yang berlaku di SMA Negeri 1 Singaraja. Peningkatan hasil belajar pada siklus II tersebut dikarenakan: (a) pengaplikasian pendekatan saintifik dan model pembelajaran kooperatif tipe TGT dengan pembelajaran berkelompok, games, dan turnamen sudah dipahami oleh peserta didik, dan (b) Peneliti melakukan perbaikan berdasarkan kendala-kendala yang dialami pada siklus I.

Meskipun pelaksanaan siklus II dinyatakan berhasil, tetapi masih terdapat kendala-kendala yang dihadapi saat pengaplikasian pendekatan saintifik dan model pembelajaran kooperatif tipe TGT, yaitu: terbatasnya waktu pelaksanaan penelitian sehingga peserta didik kekurangan waktu untuk lebih memahami tahapan-tahapan model pembelajaran yang peneliti terapkan. Dengan adanya kendala tersebut solusi yang peneliti sarankan yaitu untuk selanjutnya agar lebih sering pengaplikasian pendekatan saintifik dan model pembelajaran kooperatif tipe TGT dalam pembelajaran PJOK, sehingga peserta didik akan semakin paham dengan struktur pembelajaran dalam pengaplikasian pendekatan saintifik dan model pembelajaran kooperatif tipe TGT.

Peningkatan hasil belajar dalam penelitian ini tidak terlepas dari kelebihan-kelebihan pengaplikasian pendekatan saintifik dan model pembelajaran kooperatif tipe TGT yang menjadikan setiap peserta didik menjadi lebih siap dalam mengikuti pembelajaran khususnya dalam pembelajaran PJOK, serta dikarenakan penerapan model pembelajaran ini mengarahkan agar peserta didik yang pandai dapat mengajarkan peserta didik yang kurang pandai, sehingga secara otomatis peserta didik yang kurang pandai mendapatkan dampak yang positif.

Hasil belajar peserta didik dapat meningkat juga disebabkan karena dalam proses pembelajaran peserta didik telah mampu belajar dan beraktifitas sendiri untuk memperoleh pengalaman, pengetahuan, pemahaman dan tingkah laku lainnya, mampu bekerjasama dengan temannya, mengembangkan keterampilan yang dimiliki serta sudah mulai sangat aktif dan antusias selama proses pembelajaran sehingga dapat memahami materi pelajaran dengan sangat baik (Hamalik, 2008: 171).

Hasil penelitian ini juga dikuatkan oleh hasil penelitian dari peneliti-peneliti sebelumnya, diantaranya: (a) Fitri (2008:171) menyatakan, hasil belajar materi keragaman bentuk muka bumi meningkat melalui penggunaan model pembelajaran kooperatif tipe TGT pada siswa Kelas VII SMP Negeri 1 Purwodadi Kabupaten Pasuruan tahun pelajaran 2008/2009. Persentase keaktifan aktivitas belajar secara klasikal pada siklus I sebesar 79,70\%, persentase keaktifan aktivitas belajar secara klasikal pada siklus II sebesar 84,19\%. Sedangkan persentase ketuntasan hasil belajar secara klasikal pada siklus I 
sebesar 72,16\%, persentase ketuntasan hasil belajar secara klasikal pada siklus II sebesar 79,46\%. (b) Siti (2012:5) menyatakan, pembelajaran pemahaman konsep koperasi meningkat melalui implementasi model kooperatif tipe TGT pada siswa kelas IV SD Negeri Tambi Watukumpul Pemalang Tahun 2012/2013. Persentase ketuntasan hasil belajar secara klasikal pada siklus I sebesar 75\%, persentase ketuntasan hasil belajar secara klasikal pada siklus II sebesar 90\%. (c) Budi (2012:123-124) menyatakan, aktivitas dan hasil belajar berguling (roll) senam lantai meningkat melalui penerapan model pembelajaran kooperatif tipe TGT pada siswa kelas XI-S2 SMA Negeri Tabanan tahun pelajaran 2011/2012.

Persentase keaktifan aktivitas belajar secara klasikal pada siklus I sebesar 7,65, persentase keaktifan aktivitas belajar secara klasikal pada siklus II sebesar 9,41. Sedangkan persentase ketuntasan hasil belajar secara klasikal pada siklus I sebesar 82,4\%, persentase ketuntasan hasil belajar secara klasikal pada siklus II sebesar 85,3\%. (d) Jayadi (2012:104-105) menyatakan, aktivitas dan hasil belajar lompat jauh meningkat melalui impelementasi model pembelajaran kooperatif tipe TGT pada siswa kelas X-1 SMA Negeri Payangan tahun pelajaran 2011/2012. Persentase keaktifan aktivitas belajar secara klasikal pada siklus I sebesar 7,31 persentase keaktifan aktivitas belajar secara klasikal pada siklus II sebesar 9,27\%. Sedangkan persentase KETUNTASAN hasil belajar secara klasikal pada siklus I sebesar 85,29\%, persentase ketuntasan hasil belajar secara klasikal pada siklus II sebesar 94,12\%. (e) Doni (2012:110-111) menyatakan, aktivitas dan hasil belajar teknik pergantian tongkat lari estafet meningkat melalui impelementasi model pembelajaran kooperatif tipe TGT pada siswa kelas IX.3 SMP Laboratorium UNDIKSHA Singaraja tahun pelajaran 2011/2012. Persentase keaktifan aktivitas belajar secara klasikal pada siklus I sebesar 6,72 persentase keaktifan aktivitas belajar secara klasikal pada siklus II sebesar 7,84. Sedangkan persentase ketuntasan hasil belajar secara klasikal pada siklus I sebesar 82,5\%, persentase ketuntasan hasil belajar secara klasikal pada siklus II sebesar 100\%.

\section{KESIMPULAN DAN SARAN}

Berdasarkan hasil analisis data dan pembahasan di atas dapat disimpulkan bahwa hasil belajar taktik dan strategi perlombaan atletik lempar lembing meningkat melalui penerapan model pembelajaran kooperatif tipe TGT pada peserta didik XII MIPA 1 SMA Negeri 1 Singaraja tahun pelajaran 2017/2018.

Berdasarkan simpulan di atas, dapat dikemukakan saran-saran sebagai berikut: 1) Diharapkan kepada para peserta didik yang dijadikan subjek penelitian selanjutnya lebih memperhatikan dan memahami pembelajaran yang diberikan, khususunya dalam pembelajaran PJOK, 2) Kepada guru PJOK dapat mengaplikasikan model pembelajaran kooperatif tipe TGT pada pembelajaran taktik dan strategi perlombaan atletik lempar lembing karena dapat meningkatkan hasil belajar taktik dan strategi perlombaan atletik lempar lembing, 3) Bagi sekolah agar dijadikan pedoman dalam pembelajaran PJOK khususnya pada materi pembelajaran taktik dan strategi perlombaan atletik lempar lembing, 4) Bagi peneliti lain yang akan mengadakan penelitian dapat mengaplikasikan model pembelajaran kooperatif tipe TGT sesuai dengan materi yang akan diberikan.

\section{DAFTAR PUSTAKA}

Dimyati dan Mudjiono. 2006. Belajar dan Pembelajaran. Jakarta: Rineka Cipta.

Arikunto, Suhadjono, dan Supardi. 2008. Penelitian Tindakan Kelas. Jakarta: PT Bumi Aksara. Daryanto. 2012. Model Pembelajaran Inovatif. Malang: Gava Media.

Doni Irawan, I Putu, 2012. Impelementasi Model Pembelajaran Kooperatif Tipe Teams Games Tournament (TGT) untuk Meningkatkan Aktivitas dan Hasil Belajar Teknik Pergantian Tongkat Lari Estafet pada Siswa Kelas IX.3 SMP Laboratorium UNDIKSHA Singaraja Tahun Pelajaran 2011/2012. Jurusan Pendidikan Jasmani, Kesehatan dan Rekreasi. UNDIKSHA Singaraja.

Gede Budi Pribadi, I Gusti, 2012. Penerapan Model Pembelajaran Kooperatif Tipe Teams Games Tournament (TGT) untuk Meningkatkan Aktivitas dan Hasil Belajar Berguling (ROIl) Senam Lantai pada Siswa Kelas XI. S2 SMA Negeri 2 Tabanan Tahun Pelajaran 2011/2012. Jurusan Pendidikan Jasmani, Kesehatan dan Rekreasi. Singaraja: Universitas Pendidikan Ganesha.

Handayani KD, Fitri, 2008. Pembelajaran Kooperatif Tipe Teams Games Tournament (TGT) untuk Meningkatkan Hasil Belajar Siswa Kelas VII SMP Negeri 1 Purwodadi Kabupaten Pasuruan pada Materi Keragaman Bentuk Muka Bumi. SMA Negeri 1 Serui Papua. Tersedia pada http://library. 
um.ac.id/free-contents/index.php/pub/-model- pembelajaran kooperatif- tipe- tgt- teams- gamestournament-(diunduh pada Rabu, 30 Januari 2013).

Ika Nurjanah, Siti, dkk, 2012. Penerapan Model Kooperatif Tipe TGT untuk Meningkatkan Pemahaman Konsep Koperasi pada Mata Pelajaran IPS. PGSD FKIP Universitas Sebelas Maret. Tersedia pada http://www.google.co.id (diunduh pada hari Sabtu, 01 Oktober 2016).

Juni Sastrawan, Kadek, 2012. Impelementasi Model Pembelajaran Kooperatif Tipe Teams Games Tournament (TGT) untuk Meningkatkan Aktivitas dan Hasil Belajar Tolak Peluru pada Siswa Kelas VIII E SMP Negeri 5 Singaraja Tahun Pelajaran 2011/2012. Jurusan Pendidikan Jasmani, Kesehatan dan Rekreasi. Singaraja: Universitas Pendidikan Ganesha.

Kanca, I Nyoman. 2010. Metodologi Penelitian Keolahragaan. Singaraja: Universitas Pendidikan Ganesha. Peraturan Menteri Pendidikan dan Kebudayaan Republik Indonesia Nomor No. 53 Tahun 2015 Tentang Implementasi Kurikulum Pedoman Umum Pembelajaran. 2013. Jakarta: Badan Standar Nasional Pendidikan.

Slavin, E Robert. 2010. Pembelajaran Kooperatif : Teori, riset dan Praktek. Bandung : Nusa Media. Taniredja, Tukiran, dkk, 2011. Model-Model Pembelajaran Inovatif. Bandung: CV. Alfabeta.

Trianto. 2009. Model Pembelajaran Inovatif-Progresif. Jakarta: Kencana Prenada Media Group. 